DOI 10.31558/2519-2949.2018.1.3

УДК 32:7.038.6

\author{
Груєва О. В., Держсаний заклад «Південноукраӥнський національний \\ педагогічний університет імені К. Д. Уиинського»
}

\title{
ПОЛІТИЧНИЙ АКЦІОНІЗМ: ПОНЯТТЯ, ФОРМИ, ДОСВІД ВИКОРИСТАННЯ У ПОЛІТИЧНОМУ ПРОЦЕСІ
}

\begin{abstract}
У статті концептуалізується поняття «політичний акиіонізм» як система художньо увиразнених форм політичного протесту, публічного обговорення та дискусї, у яких проявляється театралізація, ігрова компонента, видовищність, динамічність тощо. Підкреслено, що політичний акиіонізм є сукупністю спектакулярних форм політичної участі, зазвичай, протестного й провокаційного (подекуди й асоиіального) характеру з викликом існуючому політичному ладу. Аргументовано, що систему політичного акціонізму утворюють політичний перформанс, гепенінт, арт-інсталячія, стрит-арт, флешмоб, боді-арт та ін. Функціями політичного акціонізму визначено: інформачійно-комунікаційну, політичної соціалізації, політичної мобілізації. Політичний перформанс розглянено як різновид акціоністських практик, який є візуально-процесуальною композииією (грою, виступом) на політичну тематику зі символічними атрибутами, яка представлена випадковій чи запрошеній аудиторії. Політичний гепенінг визначено як акціоністську імпровізаційну форму політичної активності зі залученням ситуативних учасників, умовністю динамічно змінюваного сиенарію акиії. Політична інсталяція розглянена як просторова арткомпозиція, елементи якої у поєднанні наділені символічністю, транслюючи, маніфестуючи певні політичні ідеї. Політичний флешмоб представлений як видовищно-ігровий різновид технологій політичного акиіонізму, який полягає в одноразовому або хвилеподібному проведенні масових короткотривалих театралізованих акиій за попередньо узгодженим сиенарієм. Політичний стрітарт розглянутий як політично спрямоване вуличне мистецтво, яке переважно у межах урбанізованого простору візуалізує сочіально-політичний прочес. Представлені наукові підходи до тлумачення політичного боді-арту як виду акиіонізму, який використовує мову тіла через нанесення на нього зображень для візуалізаџії політичної самоідентифікаиії.

Ключові слова: політичний акиіонізм, постмодернізм, політичний перформанс, політичний гепенінг, політична арт-інсталяиія, політична інсталяція, політичний флешмоб (політмоб), політично спрямований боді-арт.
\end{abstract}

В останні десятиліття формується нова (некласична) естетика політики; нею пропонується оновлене бачення форм репрезентації політичних ідей і вимог. Сьогодення виражає стійкий інтерес до нестандартних ігрових форматів донесення політичних ідей; у політичному процесі дедалі сміливіше застосовуються театралізовані форми політичної участі, зазвичай протестного, провокаційного характеру. Попри збереження класичних, усталених форм політичної активності, політичний процес модифікується завдяки образним, емоційно насиченим технологіям, які можна означити поняттям «політичний акціонізм». Акціоністи активно звертаються до політичних тем і переймають традиційні форми політичної активності, видозмінюючи їх (наприклад, демонстрація монстрація, мітинг - гепенінг тощо), або пропонують абсолютно нові форми (наприклад, i-mob). Вони акцентують увагу на непередбачуваності сучасних подій, а для підкреслення цього втілюють свій задум політичної акції у креативну форму. Такі нові творчі форми інтерпретації політичних смислів потребують пояснення 3 позицій політичної науки. Отже, метою дослідження $\epsilon$ концептуалізація новітніх форм політичного акціонізму (політичний перформанс, гепенінг, інсталяція, флешмоб (політмоб), стрит-арт і боді-арт), які й утворюють, на нашу думку, систему політичного акціонізму.

Проблематика дослідження започаткована в наукових розвідках щодо сутності акціонізму (політичного акціонізму), в яких акцентовано на таких поняттях, як «гра», «ігрові технології політичного процесу», «суспільство спектаклю» («соціум спектаклю»), «спектакулярні форми протесту» (О. Андрієнко, В. Бавикіна, Г. Дебор, М. Євреїнов, А. Зайцева, О. Кулик, І. Лященко, О. Саричев та ін.); дослідники вивчають процеси театралізації політики, характерні постмодерну.

(C) Груєва О. В., 2018 
Важливе значення мають джерела, які розкривають теоретичні характеристики окремих практик політичного акціонізму (Дж. Батлер, М. Бахтін, Д. Буличева, Д. Гончаренко, С. Зонтаг, Т. Ісакова, Д. Левчик, Г. Рейнгольд, К. Станіславська, С. Шомова, Я. Шумська та ін.). Також проблема нашого дослідження увиразнена в розвідках, присвячених використанню мистецьких акціоністських практик у вітчизняній (Г. Вишеславський, О. Ліщинська, Н. Мусієнко, В. Окаринський, К. Стукалова та ін.) і зарубіжній (С. Володенков, С. Федорченко, М. Цилімпуніді та ін.) політиці.

Окреслені форми новітнього політичного активізму можна визначити як спектакулярні; активізм починає уподібнюватися колективній драматургії, гра стає атрибутом громадськополітичної активності. Політика набуває новітньої конфігурації, перетворюючись у своєрідний постмодерний спектакль. У «суспільстві спектаклю» (за Г. Дебором [2]) беззаперечними трендами стають поняття «симулякр», «віртуальність» і «спектакль (гра)». Спектакуляризація політичного активізму є результатом низки еволюційних тенденцій, як-от еволюція горизонтальних мережевих взаємодій під впливом прогресу інформаційних технологій.

Постмодернізм привніс у політику тілесність, домінування візуальних образів, спонтанність, співучасть аудиторії, інтерактивність, нелінійність тощо. Це надало нового поштовху розвитку ігрових технології в політичному процесі. Політичне постає як гра знаків (за Ж. Бодіяром [1]). Політика набула ознак видовищності, театралізації, що не випадково в умовах інформаційного вибуху та шуму: інтерес медіа та зацікавленість особи за значної кількості політичних подій може викликати або зна́чима інформація, або нестандартно представлена, яка привертає увагу найперше формою подачі, а вже потім - змістом.

Політичний акціонізм об’єднує новітні форми художнього самовираження на політичну проблематику. Вони наділені системою виражальних засобів, глибокою образністю, знаковим кодом і символікою, художнім контекстом та підтекстом. В основі політичного акціонізму - символізація, 3 вкладанням у політичні акції очевидних і завуальованих підтекстів. Політичний акціонізм $\epsilon$ соціокультурною рефлексією, формою переосмислення сталих політичних конструктів. Він вписується у соціокультурну матрицю постмодерного сьогодення, коли домінантою стає знаковосимволічна діяльність; гра візуалізує політичний процес, будь-які прояви політики. Різноманітні практики політичного акціонізму втілюють ці формати гри у вимірі процесу боротьби за владу та іiі здійснення.

Політичний акціонізм визначаємо як систему художньо увиразнених форм політичного протесту, публічного обговорення та дискусії, у яких проявляється театралізація, ігрова компонента, видовищність, динамічність тощо. Він є сукупністю спектакулярних форм політичної участі, зазвичай, протестного й провокаційного (подекуди й асоціального) характеру з викликом існуючому політичному ладу. Політичний акціонізм об'єднує низку ненасильницьких технологій протесту на перетині політичного активізму й артистизму, які спрямовані не стільки на масове охоплення аудиторії, скільки на увагу медіа й отримання подальшого публічного резонансу. Отже, політичний акціонізм представляємо як мистецько-видовищно-ігрову форму донесення політичного.

Політичний акціонізм є системою його характеристик: 1) неінституційний характер; 2) зазвичай незаангажованість у донесенні певного політичного меседжу, але водночас політичний акціонізм може представляти певну ідеологію, політичну силу, бути провідником певних політичних ідей. Творцями перформансів, гепенінгів та інших акцій $\epsilon$ як митці (які, зазвичай, політично незаангажовані), так і активні суб’єкти політики (партії, громадські організації тощо), які акціями доносять ідеологічно мотивовані меседжі; 3) ідея акції просувається для привернення уваги влади до проблеми, але первинна інтеракція здійснюється не 3 владою, а 3 глядачем, який може стати учасником акції під час іiї перебігу або ж відреагувати на неї (повідомлення у соціальних мережах, поширення фото чи відео тощо). Звідси можна вивести функції політичного акціонізму: 1) інформаційно-комунікаційна (донесення певної політичної ідеї, генерація нових політичних смислів, швидке поширення нової інформації); 2) політичної соціалізації (під впливом різноманітних акцій формується політичний світогляд особи, iї розуміння політичного; акціоністи виступають агентами політичної соціалізації); 3) політичної мобілізації (згуртування людей для просування політичної ідеї, поштовх до участі у потенційних акціях).

Політичний перформанс $є$ різновидом акціоністських практик, який $є$ візуально-процесуальною композицією (грою, виступом) на політичну тематику зі символічними атрибутами, яка представлена випадковій чи запрошеній аудиторії. Це різновид соціального перформансу, який $є$ відповіддю на злободенні політичні події; політичний публічний жест (фізичний, вербальний) зі символічним змістом. Риси політичного перформансу: 1) лаконічність, ритуальний механізм, ігрова природа для вираження політичного смислу за допомогою художніх практик; 
2) зорієнтованість на візуальний характер сприйняття та пошук символічних підтекстів (прихованих смислів); 3) поєднує жест, епатаж і провокативність, може виходити за межі загальноприйнятних етичних норм; 4) використовує стратегію шоку для руйнації стереотипності політичного мислення громадян; 5) містить елементи парадоксальності, часто - абсурдності; 6) транслює актуальні політичні проблеми через тіло людини-перформера, яке постає як знакова, символізуюча система, яка генерує нові політичні смисли; 7) створювана політичним перформером подія не відрізняється від світу повсякденності, а лише у незвичній формі апелює до проблеми; 8) для його виконання достатньо лише тіла (тіл) й публічного простору; 9) під час його проведення глядачі не залучаються у вибудовування сюжету.

Прикладами зарубіжних політичних перформансів наведемо: а) кінця 1950-х - 1970-х років: акції «Ситуаціоністського Інтернаціоналу», «Помаранчевого Інтернаціоналу» («Провотаріату»), руху їппі (йїппі), І. Захарова-Росса, В. Ленгер (Валі Експорт) та ін.; б) 1980 - 1990-х років: М. Абрамович, О. Бренер, А. Осмоловский, О. Кулик; в) від початку 2000-х років: білоруських перформерів С. Адамовича, Д. Вишнева, А. Пушкіна та Л. Русової; перформера-мігранта П. Павленського, російських арт-груп «23:59» та «Війна», панк-рок-гурт «Pussy Riot» та ін. Аналіз проаналізованих перформансів засвідчив їхню протестну природу та маніфестування антивоєнних, антикорупційних та ін. вимог, заклики до гендерної нерівності, протест проти утисків прав людини (особливо, свободи слова), наслідків комуністичного минулого тощо.

Еволюцію вітчизняного політичного акціонізму пов'язано з періодом перебудови; до початку 2000-х років різноманітні авангардні практики в політиці мали радше поодинокий характер. Перші вітчизняні політичні перформанси датовані початком 1990-х років (Ю. Соколов, О. Замковський, С. Горський, В. Кауфман, харківська «Група швидкого реагування»), 3 подальшою еволюцією у 2000-х роках (група «Революційний Експериментальний Простір», Н. Гончар, П. Армяновський та ін.). Особливо багатим матеріалом для аналізу є політичні перформанси під час Революції гідності (наприклад, перформанси із жовто-блакитним піаніно та ін.). Відзначимо перформанси «Київського культурного трибуналу», «Колективу Конкретних дат», руфера П. Ушевця, М. Куликовської.

Самобутність українського перформансу вбачаємо у його активній реакції на болісні процеси у суспільстві та державі. Перші перформанси спрямовувалися на повалення комунізму, а після проголошення незалежності - на декларування демократичних ідей, ідеї соборності України, боротьби за українську мову тощо. Від кінця 1990-х років активізувалася тематика порушень прав людини (особливо у сфері свободи слова) та «чистоти» виборчого процесу. Перформанси 2000-х років актуалізувати євроінтеграційну тематику та проблеми політики пам'яті (вшанування пам'яті жертв голодоморів, Голокосту, депортації кримських татар), з 2014 року - проблеми анексії АР Крим, збройних дій на окупованих територіях України, проблеми внутрішньо переміщених осіб тощо.

Ще однією формою політичного акціонізму $\epsilon$ політичний гепенінг - акціоністська імпровізаційна форма політичної активності зі залученням ситуативних учасників, умовністю динамічно змінюваного сценарію акції. Риси політичного гепенінгу: 1) ігрова імпровізаційність на політичну тематику; 2) глядач неодмінно є співвиконавцем гепенінгу, межа між ініціаторамивиконавцями гепенінгу та глядачем відсутня; 4) створення шокових, провокаційних ситуацій, через які присутні видають емоцію; 5) відсутність чіткого сюжету; створення атмосфери абсурду, інколи насилля для виклику асоціації з реальністю повсякдення; 6) проведення в умовах публічного простору; 7) унікальність кожного гепенінгу, неможливість його повторення (на відміну, наприклад, від політичного перформансу); 8) сприйняття дії учасників як алогічних, абсурдних і випадкових, але в кожну дію ініціатори наповнюють політичним символізмом; 9) невизначена тривалість проведення.

Прикладами політичних гепенінгів найперше є різноманітні антикомуністичні акції: польської «Помаранчевої альтернативи» В. Фридриха (Майора) (кінець 1980-х років), російських «Суспільства дурнів», «Ініціативи революційних активістів», різноманітних карнавальних псевдопартій («Субтропічна Росія», Партія любителів пива ім. А. Лінкольна, КПРС ім. Брежнєва, Партія диктатури плюралізму та ін.), рухів «Фіолетових» і «Синій вершник», акцій арт-активістки Кадо. У цих гепенінгах використовуються елементи абсурдизації, аби завуалювати протест і уникнути репресій; іронія, сарказм, гумор - основна зброя у гепенінгах. Велика кількість відомих гепенінгів стосувалася новітнього періоду розвитку країн колишнього соціалістичного табору та СРСР, позаяк гепенінги стали відбитком суспільного запиту на прояв антивладного сарказму, критику партійних $\mathrm{i}$ виборчих «брудних» ігор, практикованих «класичними» партіями та ін. причинами. 
Вітчизняний політичний гепенінг веде традицію від акцій «Променів чучхе», акцій періоду студентської «Революції на граніті»; у них пародіювалися й абсурдизувалися комуністичні ідеї. Події Помаранчевої революції, а особливо мирного періоду Революції гідності можна назвати величезним за своїм масштабом гепенінгом. Різновидом гепенінгів, які уже «прижилися» в Україні, $\epsilon$ т. зв. монстрації - акції без сценарію за аналогією з демонстрацією, але художньо представлені та змістовно абсурдизовані. При їх проведенні усі бажаючі виходять на акцію 3 плакатами (за аналогією $з$ демонстрацією), але абсурдними та часто аполітичними за змістом. Популярними датами проведення монстрацій є свята, які у радянські часи відзначалися масовими демонстраціями.

Наступна форма політичного акціонізму - політична інсталяція. Вона $є$ просторовою композицією, елементи якої у поєднанні наділені символічністю, транслюючи, маніфестуючи певні політичні ідеї. Рисами політичної інсталяції визначаємо: 1) спрямованість на зміну людиною політичного простору; 2) створення як професійними митцями, так і протестним немистецьким середовищем; 3) зоріснтованість на візуальне, невербальне сприйняття.

Сучасні арт-інсталяції політичного спрямування ведуть початок від першої половини XX століття (дадаїсти, сюрреалісти). Аналіз сучасних політичних арт-інсталяцій (Н. Азеведо, А. Вейвея, П. Каммінса, Т. Пайпера, А. Шеррі та ін.) засвідчив їх роль найперше як форми збереження, підтримки колективної пам'яті, яка спрямована на реконструкцію минулого у сучасному (пам'ять про жертви двох світових воєн, жертв Голокосту, голодоморів, громадянських воєн і под.). Інсталяції є однією із найпопулярніших акціоністських практик під час сучасних революційних подій (наприклад, під час «Арабської весни» та гонконгської «Парасолькової революції»). У них піднімаються найгостріші проблеми сьогодення (нелегальна міграція, війни, порушення прав людини, втручання у внутрішні справи суверенних країн тощо). Це засвідчує, що мистецтво арт-інсталяцій обмежене естетичними завданнями: мистецтво постає як політичний жест.

Українська політична арт-інсталяція стрімко еволюціонує, починаючи 3 початку 1990-х років (іронічно-саркастичні щодо влади роботи творчого об’єднання «Фонд Мазоха»). Особливо велику кількість політичних інсталяцій було створено у дні Революції гідності (наприклад, каркас новорічної ялинки-2014 на київському Майдані Незалежності, барикади-інсталяції Майдану, численні «географічні інсталяції», які символізували загальноукраїнський характер акції протесту та ін.). Тематика сучасних інсталяцій: символізація ідеї ненасилля та мирного життя; тематика люстрації та декомунізації; збереження колективної пам'яті; привернення уваги до резонансних подій на міжнародній арені.

Політичний флешмоб (політмоб) як форма політичного активізму є видовищно-ігровим різновидом технологій політичного акціонізму. Це одноразова або хвилеподібна масова короткотривала театралізована акція за попередньо узгодженим сценарієм. Політмоб $\epsilon$ спектакулярною мережевою взаємодію, яка здійснюється на основі горизонтальних соціальних комунікацій. Рисами політмобу виділяємо: 1) позаінституційний характер; 2) організація за посередництва інтернет-ресурсів; 3) видовищність, яскраво виражений ігровий контекст; 4) хронометричність, зазвичай - відсутність імпровізацій (характерно тільки для класичних одноразових флешмобів).

Політичний процес засвідчує велике різноманіття сучасних флешмобів як варіацій політичного акціонізму: «мовчазні» флешмоби (їх поява зумовлена владними переслідуваннями моберів); інтернет-флешмоби (т. зв. i-mob; вони відбуваються у Twitter, Facebook та інших мережах, зі створенням відповідного хештегу); хвилеподібні естафетні флешмоби (передбачають масовість акцій із передачею права на проведення акцій від особи (колективу) до наступних учасників) та ін. Абсолютна більшість політичних флешмобів мають мирний характер, але є приклади (нечисельні) переростання мирної за своєю природою акції в організоване насилля. У окремих недемократичних державах флешмоб прирівняний до інших акцій протесту (мітингів, пікетів), заборонена стихійна самоорганізація для їх проведення.

Політичний стрит-арт визначений нами як політично спрямоване вуличне мистецтво, яке, переважно у межах урбанізованого простору, візуалізує соціально-політичний процес. Рисами політичного стрит-арту визначаємо: 1) протестний характер (естетична форма протесту) або ж $є$ формою політичної рефлексії; 2) яскрава спрямованість на глядача; 3) локалізація насамперед у місцях історичних трагедій, етнічних конфліктів, соціальної, економічної чи політичної напруги; 4) неоднозначна громадська оцінка (від схвалення до порівняння 3 вандалізмом); 5) є формою швидкої реакції на резонансу політичну подію (репрезентує поточний момент, але водночас може виступати механізмом реалізації політики пам’яті); 6) схильність до анонімності (через 
провокативний і часто антирежимний характер), ухиляння від прямого контакту стрит-артера та глядача; 7) ідентифікує автора 3 певними політичними установками; 8) переважно недосконала художня техніка виконання; 9) найчастіше набуває форми графіті, трафаретних силуетів, рідше - як муралізм (трудомісткий, затратний фінансово та за часом виконання).

Сучасний політичний стрит-арт веде традицію починаючи від 1920-х років (графіті Мао Цзедуна як промоція комуністичної революції в країні, протестний стрит-арт у американських чорношкірих кварталах тощо), а широкого розповсюдження стрит-арт набуває 3 кінця 1960-х років. Наш аналіз засвідчив, що стрит-арт найвиразніше проявляться під час революцій: революційний стрит-арт трансформує радикальний художній жест у радикальний політичний, а вуличне мистецтво стає суспільним служінням. Особливий потенціал стрит-арт має в недемократичних країнах, де незважаючи владний спротив є прояви творчого протесту (як-от в Ірані, Кенії, Сирії).

Український політичний стрит-арт розвивається від середини 1990-х років, а 3 початком третього тисячоліття припадає «вибух» вуличного мистецтва 3 хвилеподібними стрибками активності, які безпосередньо корелюються зі соціально-політичною ситуацією. Національні кольори, державна символіка, поетичні цитати, обриси упізнаваних національних героїв знайшли відображення у різноманітних техніках вуличного живопису. Стрит-арт і популяризує певні ідеї, і $є$ сатирою щодо соціально-політичних проблем, і виступає політичною карикатурою щодо політиків тощо. Трагічні події в Україні останніх років дали новий поштовх політичному стрит-арту патріотичної спрямованості зі зображенням історичних і новітніх національних героїв, пропагування національних кольорів, патріотичних гасел, державницьких образів і символів. Український стрит-арт став «аранжуванням» Революції гідності (донесення о́бразів загиблих у боротьбі з режимом, батальних сцен, що слугує механізмом формування колективної свідомості, збереження пам'яті про події у суспільстві) та подальшого процесу становлення української державності.

Політичний боді-арт є видом акціонізму, який використовує мову тіла через нанесення на нього зображень для візуалізації політичної самоідентифікації. Це метод невербальної комунікації, привернення уваги людини до себе (підкреслення індивідуальності), спосіб політичної «упізнаваності» людини. Водночас, політичний боді-арт може бути лише даниною політичній моді, не пов’язуватися з груповими чи особистісними маркерами ідентичності.

Політично спрямований боді-арт відомий із стародавніх часів (символізував статус людини), але сучасного звучання набув у XX столітті, починаючи від 1910-х років (російський футуризм проголосив «вторгнення мистецтва в життя» через модифікацію тіла). Як і у випадку зі стрит-артом, наш аналіз засвідчив: кількість людей із різноманітним політично спрямованим боді-артом особливо зростає під час революцій, воєн і після них. Ставлення до політично спрямованого боді-арту у різні часи й у різних державах відрізнялося - від кримінального переслідування (як-от у СРСР), трактування його як певної хвороби (у Великій Британії уживають поняття «синя хвороба») до розуміння як естетичного авангардизму або ж як явища масової культури.

Елементи політичного боді-арту можна віднайти в татуюваннях часів Київської Русі (бояри та князі, а також злочинці), козацько-гетьманської доби (козаки-характерники); тогочасний боді-арт був показником статусу та символом. У XX столітті боді-арт був притаманний маргіналам, творчому середовищу, але сьогодні він вийшов за межі цих прошарків. В останні роки відбувся сплеск українського патріотичного боді-арту (тату-клейноди як національний варіант: державні та національні символи, орнамент-вишиванка, образи національних героїв, козацькі мотиви тощо). Видається, що патріотичний боді-арт не має бути швидкоплинною даниною моді, а виражати глибинний ідентифікаційний сенс: спогад про подію, пам'ять про національних героїв, візуальне акцентування життєвих цінностей (незалежність, свобода, віра, честь і под.).

Аналіз проаналізованих політичних акцій засвідчив протестну природу та маніфестування певних вимог мовою політичного акціонізму: виступи проти війни, корупції, гендерної нерівності, утисків прав людини тощо. Завдяки демонстративному епатажу та провокаційній формі донесення політичної ідеї, події уможливлюється підвищений інтерес до них медіа та громадськості, а найважливіше завдання усіх форм політичного акціонізму - викликати громадський резонанс.

\section{Бібліографічний список:}

1. Бодріяр Ж. Симулякри і симуляція / Ж. Бодіяр; [пер. з фр. В. Ховхун]. - К.: Основи, 2003. - 230 с.

2. Дебор Ги. Общество спектакля / Ги Дебор; [пер. с фр. С. Офертас, М. Якубович]. - М. : Логос, 1999. $224 \mathrm{c}$. 
Gruieva $O . V$. The modern forms of political actionism: analysis of political science component.

In the article political actionism is defined as a system of artistically pronounced forms of political protest, public debate and discussed, which demonstrate theatricality, game components, staginess, dynamics etc. It is underlined that political actionism is a combination of spectacular forms of political participation of protest and provocative nature (sometimes also antisocial) intended to challenge the existing political system. The author emphasizes that political activism combines a number of non-violent protest technologies at the intersection of political activism and artistry, aimed mostly and media attention and receiving further public resonance. Political activism is presented as artistic, spectacular and game form of delivering a political message.

The author proposed a system of political activism features: non-institutional character; general impartiality in delivering some political message, but attention is paid to the fact that political activism may represent a certain ideology, political force; the idea of action is promoted in order to draw attention to the problem, but the primary interaction is carried out with the spectators rather than with the authorities. The spectators may take part in the action while it is being carried out or respond to it later (through messages in social networks, sharing pictures or videos etc.).

The article argues that the system of political actionism consists of political performance, happening, art installations, street art, flash mobs, body art etc. The following functions of political actionism have been defined: information and communication (communicating a certain political idea, generation of new political meanings, rapid spread of new information); political socialization (the political outlook of people and their understanding of politics is shaped under the influence of different actions; actionists play the role of political socialization agents); political mobilization (uniting people in order to promote a political idea, enhancing participation in potential actions).

Political performance is viewed as a type of actionist practices, which is a visual and procedural composition (game, performance) on political issues with symbolic attributes that is presented to random or invited audience. Political happening is defined as an actionist, improvisational form of political activity involving casual participant with conventional and dynamically changing scenario of the action. Political installation is viewed as a spatial art composition, the combined elements of which are endowed with symbolism, transmitting and manifesting some political ideas. The article considers political flash mob as spectacular and playful kind of the political actionism technology that consists of single or wavy performance of short theatrical mass actions according to a pre-agreed scenario; it is a spectacular network interaction, which is carried out on the basis of horizontal social communication. Political street art is viewed as politically oriented street art, which visualizes the socio-political process, usually within urbanized space. The article presents scientific approaches to interpretation of political body art as a type of actionism, which uses the body language through drawing pictures on it in order to visualize the political self-identification. Political body art is defined as a method of non-verbal communication, person drawing attention to himself or herself (emphasizing the individuality), and a way of increasing the political "recognizability" of a person.

Keywords: political actionism, postmodernism, political performance, political happening, political art installation, political installation, political flash mob (political mob), politically oriented body art. 